\title{
PENDIDIKAN KARAKTER DALAM PRESPEKTIF ISLAM
}

\author{
Sukatin \\ Sekolah Tinggi Agama Islam (STAI) Muara Bulian \\ Email:shukatin@gmail.com
}

\begin{abstract}
Character education is defined as the value of education, manners, moral education, character education which aims to develop the ability of learners to provide good and bad decisions, realize the good in everyday life with a vengeance as the lofty ideals in education. Therefore, it will be executed if the character education in line with the national education system. Educational organization of the education system in a country will be different from other countries, because the education system is organized in various countries have characteristics appropriate to the cultural background of each country. In character education should involve aspects such as: cognitive, affective, conative, and psychomotor should be developed as a whole (holistic) in a cultural context. This article is the result of library research using a descriptive approach and analysis. The results of the analysis show that In Islamic education, character education is an education that has taught Al Qur'an, namely education that emphasizes Morals. Qur'an with a very firm provides real solutions to us to develop an awareness of spiritual, emotional, and intellectual is not only a theory, but $\mathrm{Al}$ Quran ordered to translate it into everyday life.
\end{abstract}

Keywords: Character Education, Islamic education

\begin{abstract}
Abstrak
Pendidikan karakter dimaknai sebagai pendidikan nilai, budi pekerti, pendidikan moral, pendidikan watak yang tujuannya untuk mengembangkan kemampuan peserta didik untuk memberikan keputusan baik buruk, mewujudkan kebaikan dalam kehidupan sehari-hari dengan sepenuh hati sebagai cita-cita luhur dalam dunia pendidikan. Oleh sebab itu, maka pendidikan karakter akan terlaksana jika selaras dengan sistem pendidikan nasional. Penyelengaraan pendidikan sistem pendidikan disebuah negara akan berbeda dengan negara lainnya, karena sistem pendidikan yang diselenggarakan diberbagai negara mempunyai ciri yang sesuai dengan latar belakang budaya masing-masing negara. Dalam pendidikan karakter harus melibatkan aspek seperti: kognitif, afektif, konatif, dan psikomotorik yang harus dikembangkan sebagai suatu keutuhan (holistik) dalam konteks kultural. Artikel ini merupakan hasil penelitian kepustakaan dengan menggunakan pendekatan dan analisis deskriptif. Hasil analisis menunjukan bahwa pendidikan karakter merupakan pendidikan yang telah diajarkan $\mathrm{Al}$ qur'an, yaitu pendidikan yang mengedepankan Akhlak. Al-Qur'an dengan sangat tegas memberikan solusi yang nyata kepada kita untuk
\end{abstract}

Nur El-Islam, Volume 5, Nomor 2, Oktober 2018 
mengembangkan kesadaran spiritual, emosional, dan intelektual yang tidak hanya menjadi teori, tetapi Al qur'an memerintahkan untuk menerjemahkannya dalam kehidupan sehari-hari.

Kata Kunci: Pendidikan Karakter, Pendidikan Islam

\section{A. Pendahuluan}

Karakter merupakan nilai-nilai perilaku manusia yang berhubungan dengan Tuhan Yang Maha Esa, diri sendiri, sesama manusia, lingkungan dan kebangsaan yang terwujud dalam pikiran, sikap, perasaan, perkataan, dan perbuatan berdasarkan norma-norma agama, hukum, tata krama, budaya dan adat istiadat.

Untuk membentuk karakter maka bagaimana pendidikan karakter bisa terlaksana apabila sistem pendidikan sendiri ternyata harus diberikan pendidikan karakter terlebih dahulu. Oleh karena itu, sistem pendidikan sejatinya harus cocok dengan program pendidikan karakter itu sendiri. Pertama, koneksitas sistem pendidikan dengan pendidikan karakter. Munculnya gagasan pendidikan karakter ini sebagai respons dari gagalnya proses pendidikan yang menghasilkan manusia-manusia yang bermoral sesuai dengan kepribadian bangsa dan agama. Lembaga pendidikan hanya berhasil mencetak manusia yang hafal akan pelajaran, pintar menjawab soal dan itu dilakukan dengan kecurangan sehingga yang didapat hanya nilai-nilai akademik tanpa nilai moral-etik. Kedua, konsistensi pendidikan karakter. Pendidikan karakter bertujuan untuk membentuk kepribadian siswa yang ideal seperti menjadi manusia yang berkarakter baik, beriman atau bertakwa kepada Tuhan Yang Maha Esa, jujur dan disiplin. Oleh karena itu dalam pelaksanaan dilapngan maka yang harus menjadi titik awal pelaksanaan pendidikan karakter itu sendiri. Dengan demikian pendidikan dapat menjadi sarana yang mampu membentuk manusia berkarakter dan tentunya semua itu dapat terwujud bila pendidikan itu sendiri berkarakter.

Penyelenggaraan pendidikan karakter yang diselenggarakan dalam sistem pendidikan disebuah Negara akan berbeda dengan Negara lainnya, karena sistem pendidikan yang diselenggarakan diberbagai Negara mempunyai cirri yang sesuai dengan latar belakang 
Negara masing-masing, dalam menganalisa dan membandingkan sistem pendidikan islam yang diselenggarakan diberbagai Negara islam maupun Negara non islam, perbandingan tersebut perbandingan pendidikan mengandung pengertian sebagai usaha menganalisa dan mempelajari secara mendalam dua hal/aspek dari sistem pelaksanaan pendidikan untuk mencari kesamaan-kesamaan yang ada dari/dalam kedua hal/aspek atau lebih tersebut. ${ }^{1}$

Artikel ini merupakan hasil penelitian kepustakaan dengan menggunakan pendekatan dan analisis deskriptif. Sedangkan tujuan yang hendak dicapai dari penelitian tersebut adalah mengungkap bagaimana sebenarnya konsep pendidikan karakter dalam prespektif islam sehingga dengan membentuk kepribadian siswa yang ideal seperti menjadi manusia yang berkarakter baik, beriman atau bertakwa kepada Tuhan Yang Maha Esa, jujur dan disiplin. Oleh karena itu dalam pelaksanaan dilapangan maka yang harus menjadi titik awal pelaksanaan pendidikan karakter itu sendiri. Dengan demikian pendidikan dapat menjadi sarana yang mampu membentuk manusia berkarakter dan tentunya semua itu dapat terwujud bila pendidikan itu sendiri berkarakter.

\section{B. Pembehasan}

\section{Pengertian Pendidikan Karakter}

Dari segi etimologi, karakter berasal dari bahasa Yunani yang berarti "to mark" atau menandai dan memfokuskan bagaimana mengaplikasikan nilai kebaikan dalam bentuk tindakan atau tingkah laku, sehingga orang yang tidak jujur, kejam, rakus dan perilaku jelek lainnya dikatakan orang berkarakter jelek. Sebaliknya, orang yang berprilaku sesuai dengan kaidah moral disebut dengan berkarakter mulia. Secara umum, istilah karakter sering diasosiasikan dengan apa yang disebut dengan temperamen yang memberinya, seolah definisi yang menekankan unsur psikososial yang dikaitkan dengan pendidikan dan konteks lingkungan. ${ }^{2}$

${ }^{1}$ Binti Maunah, Perbandingan Pendidikan Islam (Yogyakarta: Teras, 2011), h. 2.

${ }^{2}$ Doni Koesoema A., Pendidiakn Karakter (Jakarta: Grasindo, 2010), h, 79. 
Dalam bahasa Arab karakter disebut dengan istilah akhla, yang oleh Ibnu Maskawaih diartikan sebagai: hal linnafs da'iyah laha ila af'aliha min ghair fikrin wa laa ruwiyatin. Artinya sifat atau keadaan yang tertanam dalam jiwa yang paling dalam yang selanjutnya lahir dengan muda tanpa memerlukan pemikiran dan pertimbangan lagi. ${ }^{3}$

Secara akademik pendidikan karakter dimaknai sebagai pendidikan nilai, budi pekerti, pendidikan moral, pendidikan watak yang tujuannya adalah bagaimana mampu mengembangkan kemampuan peserta didik untuk memberikan keputusan baik buru, memelihara apa baik akan mewujudkan kebaikan dalam kehidupan sehari-hari dengan sepenuh hati, untuk membentuk penyempurnaan diri individu secara terus-menerus dan melatih kemampuan diri demi menuju kearah hidup yang lebih baik. Sesuai dengan tujuan pendidikan, adalah manusia yang baik. ${ }^{4}$

Secara umum pula diketahui bahwa bila setiap orang sudah menjadi orang baik maka masyarakat akan menjadi masyarakat yang baik. ${ }^{5}$ Adapun tujuan pendidikan islam menurut muhaimin ada tiga fokus, pertama, terbentuknya insan kamil mempunyai wajah persaudaraan yang menumbuhkan sikap egalitarianisme, Kedua, terciptanya insan kaffah yang memiliki dimensi-dimensi religius, budaya dan ilmiah, Ketiga, penyadaran manusia sebagai hamba dan kholifah Allah. ${ }^{6}$

Pendidikan karakter ini hendaknya dilakukan sejak usia dini, karena usia dini merupakan masa emas perkembangan (golden age) yang keberhasilannya sangat menentukan kualitas anak di masa dewasanya. Dalam masa emas ini, seluruh aspek perkembangan pada anak usia dini, memang memasuki tahap atau periode yang sangat peka. Artinya, jika tahap ini mampu dioptimalkan dengan

${ }^{3}$ Ibnu Maskawih, Tahdzib al-Akhlak wa Tathir al-A'raq (Mesir, Al Mathba'ah alMisriyah, 1934), h. 40.

${ }^{4}$ Ibid., 3-5

${ }^{5}$ Ahmad Tafsir, Filsafat Pendidikan Islam (Bandung: PT Remaja Rosda Karya. 2006), h. 9.

${ }^{6}$ A. Fatah Yasin. Dimensi-dimensi Pendidikan Islam (Malang: UIN Malang Press. 2008), h.1. 
memberikan berbagai stimulasi yang produktif, maka perkembangan anak di masa dewasa, juga akan berlangsung secara produktif.

\section{Pendidikan karakter di Indonesia}

Tujuan negara sebagaimana tujuan pendidikan juga tercantum dalam UU No.20 tahun 1989 tentang sistem pendidikan nasional yang menyebutkan: "Mencerdaskan kehidupan bangsa dan mengembangkan manusia Indonesia seutuhnya, yaitu manusia yang beriman dan bertaqwa terhadap Tuhan Yang Maha Esa dan berbudi pekerti luhur, memiliki pengetahuan dan keterampilan, kesehatan jasmani dan rohani, kepribadian yang mantap dan mandiri serta rasa tanggung jawab kemasyarakatan dan kebangsaan".

Sedang menurut GBHN tujuan pendidikan adalah: Pendidikan Nasional berdasarkan atas pancasila dan bertujuan untuk mrningkatkan ketaqwaan kepada Tuhan yang Maha Esa, kecerdasan, ketrampilan, mempertinggi budi pekerti, memperkuat kepribadian dan mempertebal semnagat kebangsaan agar manusia membangun diri sendiri serta bersama-sama bertanggung jawab atas pembangunan bangsa. ${ }^{7}$ Pendidikan karakter bukan hal baru dalam tradisi pendidikan di Indonesia. Beberapa pendidik Indonesia modern yang kita kenal seperti Soekarno telah mencoba menerapkan semangat pendidikan karakter sebagai pembentuk kepribadian dan identitas bangsa yang bertujuan menjadikan bangsa Indonesia menjadi bangsa yang berkarakter.

Pendidikan karakter di Indonesia tidak lepas dengan kondisi moralitas bangsa yang mengalami kemerosotan, hal ini menurut Abuddin Nata akar-akar penyebab krisis moral/akhlak yang terpenting adalah sebagai berikut: ${ }^{8}$

1. Krisis akhlak terjadi karena longgarnya pegangan terhadap agama yang menyebabkan hilangnya pengontrol diri dari dalam.

\footnotetext{
${ }^{7}$ Abu Ahmadi dan Nur Uhbiyati, Ilmu Pendidikan, (Rineka Cipta, Jakarta, 1991), h. 69.

${ }^{8}$ Abuddin Nata, Manajemen Pendidikan Mengatasi Pendidikan Islam di Indonesia (Jakarta: Prenada Media, 2003), h. 222.
} 
2. Krisis akhlak terjadi karena pemnbinaan moral yang dilakukan oleh orang tua, sekolah, dan masyarakat sudah kurang efektif.

3. Krisis akhlak terjadi disebabkan karena derasnya arus budaya matrealistik, hedonistik, dan sekularistik.

4. Krisis akhlak terjadi karena belum adanya kemauan yang sungguhsungguh dari pemerintah.

Di Indonesia pendidikan karakter bukan hal baru dalam tradisi pendidikan. Beberapa pendidik Indonesia modern yang kita kenal seperti Soekarno telah mencoba menerapkan semangat pendidikan karakter sebagai pembentuk kepribadian dan identitas bangsa yang bertujuan menjadikan bangsa Indonesia menjadi bangsa yang berkarakter.

Sekarang ini, pendidikan karakter juga berarti melakukan usaha sungguh-sungguh, sitematik dan berkelanjutan untuk membangkitkan dan menguatkan kesadaran serta keyakinan semua orang Indonesia bahwa tidak akan ada masa depan yang lebih baik tanpa membangun dan menguatkan karakter rakyat Indonesia. Dengan kata lain, tidak ada masa depan yang lebih baik yang bisa diwujudkan tanpa kejujuran, tanpa meningkatkan disiplin diri, tanpa kegigihan, tanpa semangat belajar yang tinggi, tanpa mengembangkan rasa tanggung jawab, tanpa memupuk persatuan di tengah-tengah kebinekaan, tanpa semangat berkontribusi bagi kemajuan bersama, serta tanpa rasa percaya diri dan optimisme. Inilah tantangan kita bangsa Indonesia. Kriteria manusia, warga masyarakat dan warga negara yang baik bagi suatu masyarakat atau bangsa secara umum didasarkan pada nilainilai sosial tertentu, yang banyak dipengaruhi oleh budaya masyarakat dan bangsanya itu sendiri. Oleh karena itu, hakekat dari pendidikan karakter dalam pendidikan di Indonesia adalah pendidikan nilai, yakni pendidikan nilai-nilai luhur yang bersumber dari budaya bangsa Indonesia sendiri serta nilai-nilai dari ajaran agama, dalam rangka membina generasi muda. Menurut UU no 20 tahun 2003 pasal 3 menyebutkan pendidikan nasional berfungsi mengembangkan kemampuan dan membentuk karakter bangsa yang bermartabat. Ada 9 pilar pendidikan berkarakter, diantaranya adalah:

a. Cinta tuhan dan segenap ciptaannya 
b. Tanggung jawab, kedisiplinan dan kemandirian

c. Kejujuran /amanah dan kearifan

d. Hormat dan santun

e. Dermawan, suka menolong dan gotong royong/ kerjasama

f. Percaya diri, kreatif dan bekerja keras

g. Kepemimpinan dan keadilan

h. Baik dan rendah hati

i. Toleransi kedamaian

Pendidikan karakter merupakan proses panjang yang tidak perna berakhir (never ending proses), dimana pendidikan karakter harus menjadi bagian terpadu dari pendidikan. ada beberapa aspek seperti: kognitif, afektif, kongitif, dan psikomotorik yang harus dikembangkan sebagai suatu keutuhan (holistik) dalam konteks kultural. Hal tersebut sebagai upaya perkembangan manusia menjadi manusia kaafah, oleh karena itu dalam membentuk karakter anak diperlukan keteladanan sejak dini dilingkungan keluarga dengan pola asuh yang terkenal dengan sebutan parenting style. ${ }^{9}$

Lembaga pendidikan memiliki peran yang sangat penting dalam pembentukan karakter peserta didik, hal tersebut terintegral dari tujuan pendidikan. Upaya pembentukan karakter harus mengarah pada pembaharuan kurikulum sehingga pendidikan Islam mampu menjadikan peserta didik sebagai manusia yang berkarakter sesuai dengan yang dicita-citakan. ${ }^{10}$

Kementerian Pendidikan Nasional telah mengembangkan grand design pendidikan karakter nasional pada semua jalur dan jenjang pendidikan sebagai rujukan konseptual dan operasional pengembangan, pelaksanaan dan penilaian. Grand design tersebut merupakan konfigurasi karakter dalam konteks total proses psikologis dan sosial-kultural, yaitu meliputi: olah hati (spiritual and emotional development), olah pikir (intellectual development), olah raga dan

\footnotetext{
${ }^{9}$ Thomas Lickona, Educating for Character; Mendidik untuk Membentuk karakter, Sukses Offset (Jakarta, PT. Bumi Aksara, 2012), h. viii.

${ }^{10}$ Juwariyah, Dasar-dasar Pendidikan Anak dalan al-Qur'an (Yogyakarta: Teras, 2010), h. 2 .
} 
kinestetik (physical and kinestetic development), dan olah rasa dan karsa (affective and creatif development). ${ }^{11}$

Pengembangan pendidikan karakter tidak lepas dari pribadi dari masing-masing individu, keluarga, masyarakat, wilayah dan nasional. Dengan potensi Illahiyah yang dimiliki anak didik, pendidikan dan bimbingan dari orang tua, guru dan masyarakat. sehingga membentuk karakter, sedangkan karakter akan mempengaruhi perilaku. Dengan menempatkan pendidikan karakter dalam kerangka dinamika dan dialektika proses pembentukan individu, para insan pendidik diharapkan semakin dapat menyadari pentingnya pendidikan karakter sebagai sarana pembentuk pedoman perilaku, pembentukan akhlak, dan pengayaan nilai individu dengan cara menyediakan ruang bagi figur keteladanan dan menciptakan sebuah lingkungan yang kondusif bagi proses pertumbuhan, berupa kenyamanan dan keamanan yang membantu suasana pengembangan diri satu sama lain dalam keseluruhan dimensinya (teknis, intelektual, psikologis, moral, sosial, estetis, dan religius). Tujuannya adalah untuk menjadi warga masyarakat yang baik, dan warga negara yang baik.

\section{Pendidikan Karakter dalam Prespektif Islam}

Pendidikan Islam seharusnya merupakan pendidikan yang bergerak "dari dalam ke luar" yakni pendidikan yang bertumpu pada pembentukan karakter (character building) pada setiap individu yang akan secara dinamis bergerak membentuk karakter kelompok, jama'ah, dan umat. Pendidikan ini dalam Islam disebut sebagai pendidikan akhlak. Allah selalu menargetkan kondisi makarim alakhlaq (akhlak terpuji) dalam pencapian target pendidikan.

Konsep al-Qur'an tentang pendidikan lebih mengedepankan pendidikan akhlak (karakter). Sebagiamana menurut Yusuf Qaradhawi menjelaskan bahwa: "pendidikan Islam adalah pendidikan manusia seutuhnya baik akal maupun hati; rohani dan jasmani; akhlak dan keterampilan. Sebab pendidikan Islam menyiapkan manusia untuk

${ }^{11}$ Novan Ardy Wiyani, Pendidikan Karakter Berbasis Iman dan Taqwa (Yogyakarta: Teras, 2012), h. 13. 
hidup, baik dalam perang dan menyiapkan untuk menghadapi masyarakat dengan segala kebaikan dsn kesejahteraannya, manis dan pahitnya. ${ }^{12}$

Konsep pendidikan Barat yang hanya berorientasi pada kecerdasan intelektual belaka (intellectual minded) dan kering akan nilai-nilai kecerdasan spiritual. Bersamaan dengan itu ditemukannya faktaneka keilmuan yang berhasil mereka maklumatkan dalam basis keilmuan. Disamping itu bentuk konkrit dari konsep ini telah memunculkan kemajuan teknologi yang menyebabkan manusia lebih mudah dalam "menguasai" atau bahkan mengeksploitasi dunia, yang pada kelanjutannya akan membuat hancurnya peradaban manusia. Pendidikan yang intellectual minded sudah sangat pasti melahirkan generasi yang berorientasi pada duniawi. Maka tidak heran jika masih banyak koruptor yang berkeliaran di negeri yang mayoritas penduduknya beragama Islam ini.

Bangsa kita ini sudah mengalami sindrom kegamangan karakter. Ketiga hal ini tentu saja berangkat dari konsep yang sudah diajarkan oleh al-Qur'an 14 abad silam. Spiritual Internalization atau tauhid (Q.S. al-Ikhlash: 1-4), emotional values empowering atau tadzhibu al-akhlaqi (seperti dalam Q.S. al-Hujurat: 2), penalaran intelektual atau intellectual empowering (Q.S. al-'Alaq: 1-5), dan penjabaran sosial atau socialization (Q.S. Fushilat: 33). Ini semua berangkat dari al-Qur'an. Dengan kenyataan seperti ini, sudah barang tentu kita harus kembali merujuk kepada al-Qur'an untuk membentuk pendidikan karakter yang memang sudah sangat kering terasa di negeri ini. Al-Qur'an dengan sangat tegas memberikan solusi yang nyata kepada kita untuk mengembangkan kesadaran spiritual, emosional, dan intelektual yang tidak hanya sekedar bergerak pada tataran teori namun "menguap" pada kenyataan sosial dalam lingkungan masyarakat bahkan juga dapat dirasakan oleh makhluk Allah yang lain. Inilah yang sering disebut sebagai Islam. Karakter yang baik adalah hasil internalisasi

${ }^{12}$ Novan Ardy Wiyani, Pendidikan Karakter Berbasis Iman dan Taqwa (Yogyakarta: Teras, 2012), h.13. 
nilai-nilai agama dan moral pada diri seseorang yang ditandai oleh sikap dan perilaku yang positif.

Seorang mukmin yang memiliki ilmu (kognitif/knowledge), dan mampu memanfaatkan ilmunya dalam kehidupan, sebagai amalnya (motorik/skill) dengan akhlak mulia (nilai dan sikap/attitude), sehingga berdampak rahmatan lil alamin. Individu yang berkarakter sesuai dengan ajaran Islam adalah pribadi yang integral, yaitu integrasi antara iman, ilmu dan amal. ${ }^{13}$

\section{Dasar-dasar Pendidikan Karakter Perspektif Islam}

Salah satu ayat yang menerangkan tentang pendidikan karakter adalah Q.S Luqman ayat 12-24, Walaupun terdapat banyak ayat AlQur'an yang memiliki keterkaitan dengan pendidikan karakter, namun Q.S Luqman ayat 12-14 karena ayat ini mewakili pembahasan ayat yang memiliki keterkaitan makna paling dekat dengan konsep pendidikan karakter. ${ }^{14}$ Allah SWT berfirman:

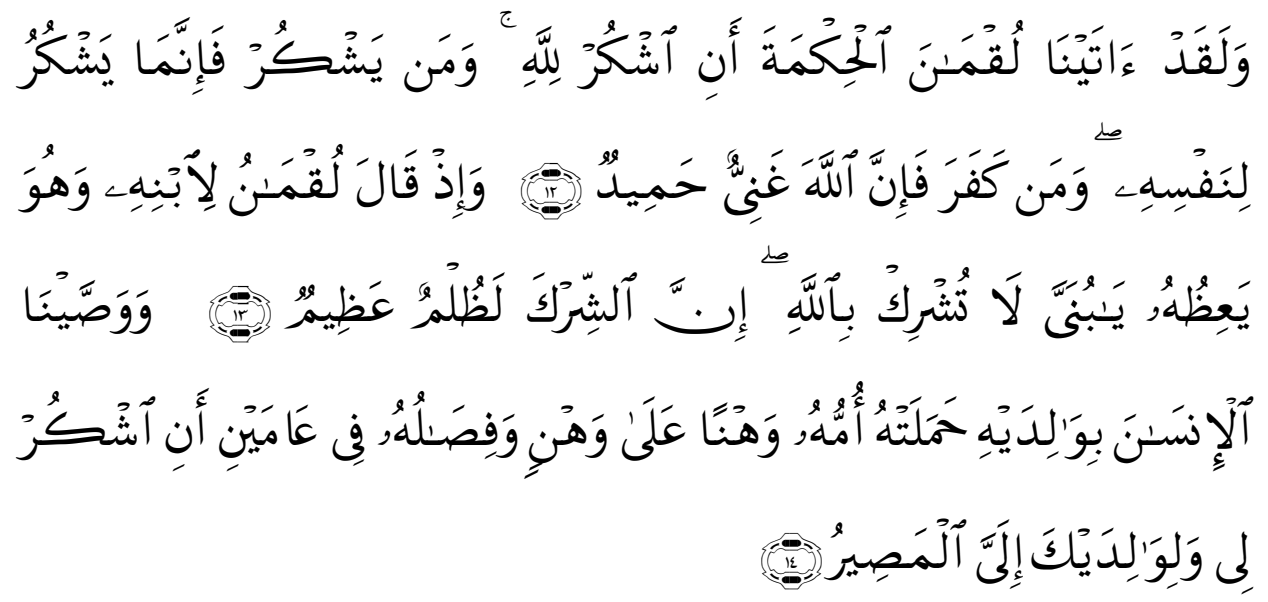

\footnotetext{
${ }^{13}$ Heri Gunawan, Kurikulum Dan Pembelajaran Pendidikan Agama Islam (Alfabeta, Bandung, 2013), h. 209.

${ }^{14}$ http://www.tafsir.web.id/2013/03/tafsir_luqman ayat 12-14.html
} 
"Dan Sesungguhnya telah Kami berikan hikmat kepada Luqman, Yaitu: "Bersyukurlah kepada Allah. dan Barangsiapa yang bersyukur (kepada Allah), Maka Sesungguhnya ia bersyukur untuk dirinya sendiri; dan Barangsiapa yang tidak bersyukur, Maka Sesungguhnya Allah Maha Kaya lagi Maha Terpuji". dan (ingatlah) ketika Luqman berkata kepada anaknya, di waktu ia memberi pelajaran kepadanya: "Hai anakku, janganlah kamu mempersekutukan Allah, Sesungguhnya mempersekutukan (Allah) adalah benar-benar kezaliman yang besar". dan Kami perintahkan kepada manusia (berbuat baik) kepada dua orang ibu- bapanya; ibunya telah mengandungnya dalam Keadaan lemah yang bertambah- tambah, dan menyapihnya dalam dua tahun[1180]. bersyukurlah kepadaku dan kepada dua orang ibu bapakmu, hanya kepada-Kulah kembalimu. (Q.S. al-Lukman 12-14).

Aspek personal Luqman Jika dilihat dalam perspektif pendidikan yaitu bahwa kualitas manusia tidak dipandang dari sudut keturunan atau ras. Figur Luqman sebagai seorang pendidik memiliki kelebihan dalam kualitas kepribadiannya bukan kelebihan dalam bentuk kepemilikan berupa material maupun keturunan. Kelebihan dalam konteks ini yaitu hikmah. Luqman dipandang sebagai figur pendidik yang memiliki sifat dan perilaku yang menggambarkan hikmah. Dalam tafsir Ath-Thabari, hikmah diartikan sebagai pemahaman dalam agama, kekuatan berfikir, ketepatan dalam berbicara, dan pemahaman dalam Islam meskipun ia bukan nabi dan tidak diwahyukan kepadanya.

Implikasi dari makna hikmah bagi figur pendidik adalah bahwa seorang pendidik selain senantiasa berusaha meningkatkan kemampuan akademiknya, ia pun berupaya menselaraskan dengan amalannya. Sebagaimana dijelaskan dalam sebuah hadits yang diriwayatkan oleh Imam Al-Bukhari dalam kitabul 'ilmi bab Al-Igtibat fil 'ilmi wal hihmah. Ketika menjelaskan bolehnya hasad, salah satunya kepada seseorang yang Allah berikan hikmah lalu ia amalkan dan ajarkan kepada orang lain. Kemudian pada surah Luqman ayat 12 terdapat pula kata "syukur". Konsep syukur dalam ayat ini, menyiratkan pemahaman pendidik terhadap dirinya sendiri yang 
menjadi bagian dari nilai pendidikan, yaitu sebagai salah satu syarat yang harus dimiliki oleh pendidik. Adapun makna syukur berarti meningkatkan seluruh potensi yang diberikan oleh Allah baik fisik, mental maupun spiritual. Adapun bentuknya, yaitu: Pertama, dengan mengucapkan Alhamdulillah. Kedua, dengan merasakan dan menikmati dengan segenap jiwa dan raga. Ketiga, menjadikannya sebagai pemicu untuk meningkatkan kualitas hidup, ibadah, amal baik dan prestasi.

Dalam ayat 13, Allah mengabarkan tentang wasiat Luqman kepada anaknya, yaitu Luqman bin 'Anqa bin Sadun, dan nama anaknya Tsaran, agar anaknya tersebut hanya menyembah Allah semata dan tidak menyekutukannya dengan sesuatu apapun. Ungkapan "la tusyrik billah" dalam ayat ini, memberi makna bahwa ketauhidan merupakan materi pendidikan terpenting yang harus ditanamkan pendidik kepada anak didiknya karena hal tersebut merupakan sumber petunjuk ilahi yang akan melahirkan rasa aman. Sebagaimana firman Allah: "Orang-orang yang beriman dan tidak mencampuradukkan iman mereka dengan kezaliman (syirik), mereka itulah yang mendapat keamanan dan mereka itu adalah orang-orang yang mendapat petunjuk." Penyampaian materi pendidikan dalam ayat ini, diawali dengan penggunaan kata "Ya bunayya" (wahai anakku) merupakan bentuk tashgir (diminutif) dalam arti belas kasih dan rasa cinta, bukan bentuk diminutif penghinaan atau pengecilan. Itu artinya bahwa pendidikan harus berlandaskan aqidah dan komunikasi efektif antara pendidik dan anak didik yang didorong oleh rasa kasih sayang serta direalisasikan dalam pemberian bimbingan dan arahan agar anak didiknya terhindar dari perbuatan yang dilarang. Oleh karena itu, Al-Ghazali dalam "Ihya "Ulumuddin" menyebutkan bahwa salah satu diantara tugas pendidik ialah menyayangi anak didiknya sebagaimana seorang ayah menyayangi anaknya, bahkan lebih. Dan selalu menasehati serta mencegah anak didiknya agar terhindar dari akhlak tercela.

Dari segi anak didik, ungkapan "la tusyrik billah innassyirka lazhulmun azhim" (janganlah kamu mempersekutukan Allah, sesungguhnya mempersekutukan Allah adalah benar-benar kezaliman 
yang besar) mengandung arti bahwa sesuatu yang tidak boleh dilakukan oleh anak didik tidak hanya sebatas larangan, tetapi juga diberi argumentasi yang jelas mengapa perbuatan itu dilarang. Anak didik diajak berdialog dengan menggunakan potensi pikirnya agar potensi itu dapat berkembang dengan baik. Komunikasi efektif antara Luqman dan anaknya mengisyaratkan bahwa hendaknya seorang pendidik menempatkan anak didiknya sebagai objek yang memiliki potensi fikir.

Dari segi lain, ungkapan “Janganlah kamu mempersekutukan Allah, sesungguhnya mempersekutukan Allah adalah benar-benar kedzaliman yang besar" menimbulkan rasa kehati-hatian di diri anak didik dalam melakukan kewajiban kepada Allah serta usaha untuk menghindar dari persoalan yang dilarang, sehingga dengan demikian materi pendidikan lebih mudah diterima anak didik.

Adapun makna yang dapat diungkap dalam ayat 14 adalah bahwa pendidikan Luqman tidak terbatas pada pendidikan yang dilakukan orang tua kepada anaknya dalam keluarga, karena ayat yang berisi pesan berbuat baik kepada kedua orang tua ini diletakkan di tengahtengah konteks pembicaraan peristiwa Luqman. Dengan demikian, wasiat Luqman kepada anaknya menjadi dasar bagi pendidikan pada umumnya baik dalam keluarga maupun yang lainnya, yaitu antara lain upaya mendidik anak untuk berbuat baik kepada orang tuanya.

Dalam ayat 14 ini materi berbuat baik kepada kedua orang tua disampaikan melalui anjuran untuk menghayati penderitaan dan susah payah ibunya selama mengandung. Metode seperti ini merupakan cara memberi pengaruh dengan menggugah emosi anak didik, sehingga berdampak kuat terhadap perubahan sikap dan perilaku sesuai dengan tujuan yang diinginkan.

Adapun nilai karakter yang termaktub dalam QS. Luqman ayat 12-14 tadi, yang pertama, dari seorang Luqman, pendidik hendaknya mempunyai karakter hikmah, yakni berpengetahuan dan berilmu. Artinya, selain mempunyai pengetahuan, pendidik juga dituntut untuk mengamalkan pengetahuannya. Kedua, pendidikan karakter yang terdapat dalam QS. Luqman diatas adalah anjuran untuk menjadikan individu-individu yang bersyukur, syukur dalam artian tidak hanya 
mengucapkan Alhamdulillah, ,melainkan menikmati segala karunia Allah untuk pemicu dalam meningkatkan prestasi, ketiga nilai karakter yang ada pada ayat ini adalah menjadikan Tauhid atau Aqidah sebagai pondasi awal bagi anak sebelum anak mengenal disiplin ilmu pengetahuan yang lain. Keempat, Luqman memanggil anaknya dengan sebutan Ya Bunayya, padahal bahasa arab yang biasa digunakan adalah Ya Ibnii, Ya Bunayaa adalah bahasa yang sangat halus yang digunakan oleh orang tua kepada anaknya, nilai karakter yang ada pada ayat ini adalah, hendaknya bagi para pendidik untuk bertutur halus kepada anak didiknya. Kelima, pada ayat diatas juga diperintahkan untuk merenungi penderitaan seorang ibu yang mengandung anaknya dalam keadaan wahnan 'ala wahnin, nilai karakter pada ayat ini adalah nilai bakti seorang anak kepada orang tuanya, khususnya kepada ibu. Keenam, penutup ayat ini Ilayyal Mashiir semua akan kembali kepada Allah, nilai karakter darinya adalah siapapun kita sebagai manusia pasti akan kembali kepada Allah, dan ini melahirkan nilai-nilai ketakwaan, karena hanya taqwa lah yang akan menjadikan manusia berbeda dihadapan Allah ketika kembali keharibaannya.

Hadits nabi yang berkaitan dengan konsep pendidikan karakter adalah hadits yang diriwayatkan oleh imam Bukhari-Muslim sebagai berikut:

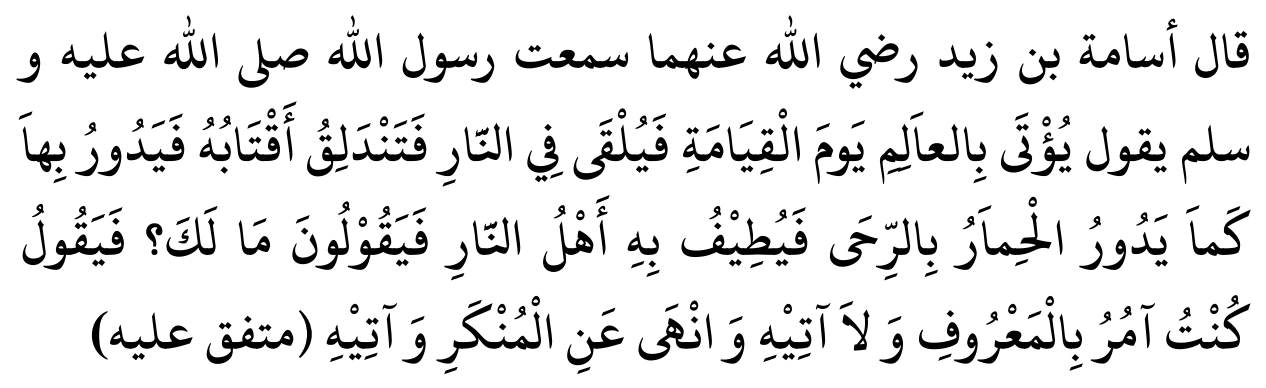

"Usamah bin Zaid ra. berkata: Saya mendengar Rasulullah saw. bersabda: Akan dihadapkan orang yang berilmu pada hari kiamat, lalu keluarlah semua isi perutnya, lalu ia berputar-putar dengannya, 
sebagaimana himar yang ber-putar-putar mengelilingi tempat tambatannya. Lalu penghuni neraka disuruh mengelilinginya seraya bertanya: Apakah yang menimpamu? Dia menjawab: Saya pernah menyuruh orang pada kebaikan, tetapi saya sendiri tidak mengerjakan-nya, dan saya mencegah orang dari kejahatan, tetapi saya sendiri yang mengerjakannya”. (Muttafaq Alaih).

Menurut tinjuan Abubakar Muhammad dalam bukunya Hadits Tarbawi, hadits ini beberapa pelajaran yang harus diperhatikan oleh para sarjana khususnya dan orang-orang yang berilmu pada khususnya:

1) Setiap orang yang berilmu, teritama para ulama, sarjana, pembesar, guru dan dosen, termasuk para muballigh dan khotib, harus konsekuen mengamalkan ilmunya untuk kesejahteraan umat manusia.

2) Semua orang berilmu harus menjadi teladan bagi orang lain da lam tutur kata dan tingkah lakunya.

3) Orang berilmu yang tidak konsekuen dengan tutur katanya, diancam dengan siksaan yang berat dalam neraka kelak.

4) Dalam hadits tersebut terkandung larangan kepada para pembesar, ulama, muballigh, guru dan dosen, berakhlak tercela.

Dalam hadits riwayat Bukhori-Muslim di atas menguraikan bahwa pembentukan karakter yang didasari keteladanan akan menuai kebaikan bagi dirinya sendiri dan orang lain. Dengan bukti adanya siksa Allah bagi orang yang hanya memerintahkan suatu kebaikan namun ia tidak turut menjalankannya. Oleh karenanya, pengaruh keluarga sebagai tempat pendidikan pertama bagi sang anak harus berupa orang-orang yang baik pula.

Dalam perspektif Islam, karakter atau akhlak mulia merupakan buah yang dihasilkan dari proses penerapan syariah (ibadah dan muamalah) yang dilandasi oleh fondasi aqidah yang kokoh. Ibarat bangunan, karakter/akhlak merupakan kesempurnaan dari bangunan tersebut setelah fondasi dan bangunannya kuat. Jadi, tidak mungkin karakter mulia akan terwujud pada diri seseorang jika ia tidak memiliki aqidah dan syariah yang benar. Seorang Muslim yang 
memiliki aqidah atau iman yang benar pasti akan terwujud pada sikap dan perilaku sehari-hari yang didasari oleh imannya. Sebagai contoh, orang yang memiliki iman yang benar kepada Allah ia akan selalu mengikuti seluruh perintah Allah dan menjauhi seluruh laranganlarangan-Nya. Dengan demikian, ia akan selalu berbuat yang baik dan menjauhi hal-hal yang dilarang (buruk). Iman kepada yang lain (malaikat, kitab, dan seterusnya) akan menjadikan sikap dan perilakunya terarah dan terkendali, sehingga akan mewujudkan akhlak atau karakter mulia. Hal yang sama juga terjadi dalam hal pelaksanaan syariah. Semua ketentuan syariah Islam bermuara pada terwujudnya akhlak atau karakter mulia. Seorang yang melaksanakan shalat yang sesuai dengan ketentuan yang berlaku, misalnya, pastilah akan membawanya untuk selalu berbuat yang benar dan terhindar dari perbuatan keji dan munkar. ${ }^{15} \mathrm{Hal}$ ini dipertegas oleh Allah dalam alQuran (QS. al-Ankabut [29]: 45).

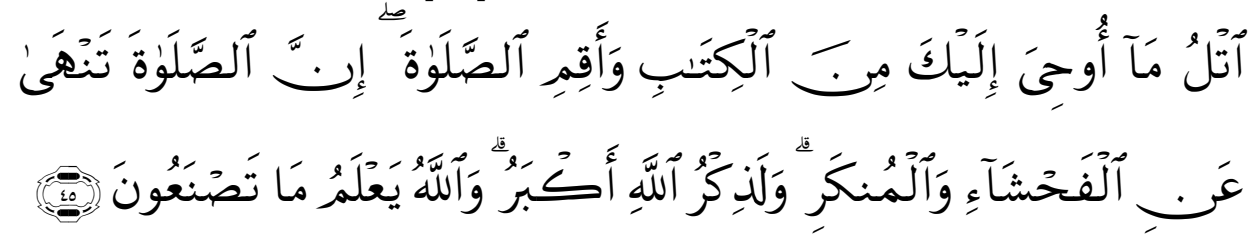

"Bacalah apa yang telah diwahyukan kepadamu, Yaitu Al kitab (Al Quran) dan dirikanlah shalat. Sesungguhnya shalat itu mencegah dari (perbuatan- perbuatan) keji dan mungkar. dan Sesungguhnya mengingat Allah (shalat) adalah lebih besar (keutamaannya dari ibadat-ibadat yang lain). dan Allah mengetahui apa yang kamu kerjakan. (Q.S Al-Ankabut: 45).

Demikianlah hikmah pelaksanaan syariah dalam hal shalat yang juga terjadi pada ketentuan-ketentuan syariah lainnya seperti zakat, puasa, haji, dan lainnya. Hal yang sama juga terjadi dalam pelaksanaan muamalah, seperti perkawinan, perekonomian, pemerintahan, dan lain sebagainya. Kepatuhan akan aturan muamalah

${ }^{15}$ Marzuki. Prinsip Dasar Akhlak Mulia: Pengantar Studi Konsep-Konsep Dasar Etika dalam Islam( Yogyakarta: Debut Wahana Press-FISE UNY:2009), h. 234. 
akan membawa pada sikap dan perilaku seseorang yang mulia dalam segala aspek kehidupannya. Mengkaji dan mendalami konsep akhlak bukanlah yang terpenting, tetapi merupakan sarana yang dapat mengantarkan seseorang dapat bersikap dan berperilaku mulia seperti yang dipesankan oleh Nabi saw. Dengan pemahaman yang jelas dan benar tentang konsep akhlak, seseorang akan memiliki pijakan dan pedoman untuk mengarahkannya pada tingkah laku sehari-hari, sehingga dapat dipahami apakah yang dilakukannya benar atau tidak, termasuk karakter mulia (akhlaq mahmudah) atau karakter tercela (akhlaq madzmumah). Baik dan buruk karakter manusia sangat tergantung pada tata nilai yang dijadikan pijakannya. Abul A'la alMaududi membagi sistem moralitas menjadi dua. Pertama, sistem moral yang berdasar kepada kepercayaan kepada Tuhan dan kehidupan setelah mati. Kedua, sistem moral yang tidak mempercayai Tuhan dan timbul dari sumber-sumber sekuler (al-Maududi, 1984: 9). Sistem moralitas yang pertama sering juga disebut dengan moral agama, sedang sistem moralitas yang kedua sering disebut moral sekular. Sistem moralitas yang pertama (moral agama) dapat ditemukan pada system moralitas Islam (akhlak Islam). Hal ini karena Islam menghendaki dikembangkannya al-akhlaq al-karimah yang pola perilakunya dilandasi dan untuk mewujudkan nilai Iman, Islam, dan Ihsan. Iman sebagai al-quwwah al-dakhiliah, kekuatan dari dalam yang membimbing orang terus melakukan muraqabah (mendekatkan diri kepada Tuhan) dan muhasabah (melakukan perhitungan) terhadap perbuatan yang akan, sedang, dan sudah dikerjakan. Ubudiyah (pola ibadah) merupakan jalan untuk merealisasikan tujuan akhlak. Cara pertama untuk merealisasikan akhlak adalah dengan mengikatkan jiwa manusia dengan ukuran-ukuran peribadatan kepada Allah. Karakter tidak akan tampak dalam perilaku tanpa mengikuti aturan-aturan yang ditetapkan oleh Allah Swt.

Sedangkan sistem moralitas yang kedua (moral sekular) adalah sistem yang dibuat atau sebagai hasil pemikiran manusia (secular moral philosophies) dengan mendasarkan pada sumber-sumber sekular, baik murni dari hukum yang ada dalam kehidupan, intuisi manusia, pengalaman, maupun karakter manusia. Sistem moralitas ini 
merupakan topik pembicaraan para filosof yang sering menjadi masalah penting bagi manusia, sebab sering terjadi perbedaan pendapat mengenai ketetapan baik dan buruknya perilaku, sehingga muncullah berbagai aturan perilaku dengan ketetapan ukuran baik buruk yang berbeda. Sebagai contoh adalah aliran hedonisme yang menekankan pada kebahagiaan, kenikmatan, dan kelezatan hidup duniawi.

\section{Kesimpulan}

Indonesia adalah negara yang mayotitas penduduknya beragama Islam. Jika umat Islam Indonesia memiliki karakter mulia, maka Indonesia telah berhasil membangun karakter bangsanya. Sebaliknya jika umat Islam Indonesia hanya bangga dalam hal kuantitas, tetapi tidak memperhatikan kualitas (terutama karakternya), maka Indonesia telah gagal membangun bangsanya. Artinya, ketika umat Islam benarbenar memahami ajaran agama Islam dengan baik atau mengamalkannya dalam kehidupan sehari-hari, pastilah terwujud tatanan kehidupan di tengah-tengah masyarakat yang berkarakter.

Kenyataan membuktikan bahwa Indonesia banyak bermasalah dalam hal karakter. Hal ini berarti bangsa Indonesia yang didominasi oleh umat Islam belum mengamalkan ajaran agama dengan baik. Ideide dua tokoh etika Islam (al-Asfahani dan al-Ghazali) seperti diuraikan di atas barangkali bisa dijadikan sandaran dalam meyakini kesimpulan tersebut. Untuk itu, marilah kita jadikan agama sebagai fondasi utama dalam membangun karakter manusia. Dengan agamalah karakter yang seutuhnya bisa terbangun.

\section{DAFTAR PUSTAKA}

Ahmadi, Abu dan Uhbiyati, Nur. Ilmu Pendidikan, Jakarta:, Rineka Cipta, 1991.

Dasar Etika dalam Islam. Yogyakarta: Debut Wahana Press-FISE UNY.

Gunawan, Heri, Kurikulum Dan Pembelajaran Pendidikan Agama Islam, Bandung : Alfabeta, 2013. 
http://www.tafsir.web.id/2013/03/tafsir_luqman ayat 13-14.html

Juwariyah, Dasar-dasar Pendidikan Anak dalan al-Qur'an, Yogyakarta: Teras, 2010.

Koesoema A, Doni., Pendidiakn Karakter, Jakarta: Grasindo, 2010.

Lickona, Thomas, Educating for Character; Mendidik untuk Membentuk karakter, Sukses Offset, Jakarta, PT. Bumi Aksara, 2012.

Marzuki. Prinsip Dasar Akhlak Mulia: Pengantar Studi Konsep-Konsep Dasar Etika dalam Islam, Yogyakarta: Debut Wahana Press-FISE $\mathrm{UNY}: 2009$.

Maskawih, Ibnu, Tahdzib al-Akhlak wa Tathir al-A'raq, Mesir, Al Mathba'ah al-Misriyah, 1934.

Maunah, Binti, Perbandingan Pendidikan Islam, Yogyakarta: Teras, 2011.

Nata, Abuddin, Manajemen Pendidikan Mengatasi Pendidikan Islam di Indonesia, Jakarta: Prenada Media, 2003.

Qaradhawi, Yusuf. Pendidikan Islam dan Madrasah Hasan al-Banna, terj. Bustami A. Ghani dan Zainal Abidin Ahmad, Jakarta: Bulan Bintang, 1980.

Tafsir, Ahmad, Filsafat Pendidikan Islam, Bandung: PT Remaja Rosda Karya, 2006.

Wiyani, Novan Ardy. Pendidikan Karakter Berbasis Iman dan Taqwa, Yogyakarta: Teras, 2012.

Yasin, A. Fatah. Dimensi-dimensi Pendidikan Islam. Malang: UIN Malang Press, 2008. 